\title{
Influence of Lactobacillus plantarum Lp6 fermentation on the functional properties of soybean protein meal
}

\author{
Issoufou Amadou*, Tidjani Amza, M. B. K. Foh, M. T. Kamara \\ and Guo-Wei Le
}

\begin{abstract}
State Key Laboratory of Food Science and Technology, Jiangnan University, No. 1800 Lihu Road, Wuxi, 214122, Jiangsu Province, P. R. China
\end{abstract}

\begin{abstract}
Soybean protein meal was subjected to solid state fermentation with Lactobacillus plantarum Lp6 either in the presence or absence of a protease. Soybean meals were investigated for functional properties including nitrogen solubility, emulsifying activity, foaming capacity, foaming stability, differential scanning calorimetry and in vitro protein digestibility. The data showed significant $(\mathrm{P}<0.05)$ variations among the soybean meal samples. The fermented soybean protein meal (FSPM) with added protease (FSPMe) showed higher denaturing temperature $\left(103.77^{\circ} \mathrm{C}\right)$ compared to $61.67^{\circ} \mathrm{C}$ exhibited by unfermented soybean protein meal (SPM). The functional properties of soybean protein meals prepared from the two conditions (L. plantarum Lp6 plus or without added protease) showed insignificant changes when compared with the unfermented SPM.
\end{abstract}

Keywords: Fermentation, L. plantarum Lp6, Soybean protein meal, Functional properties.

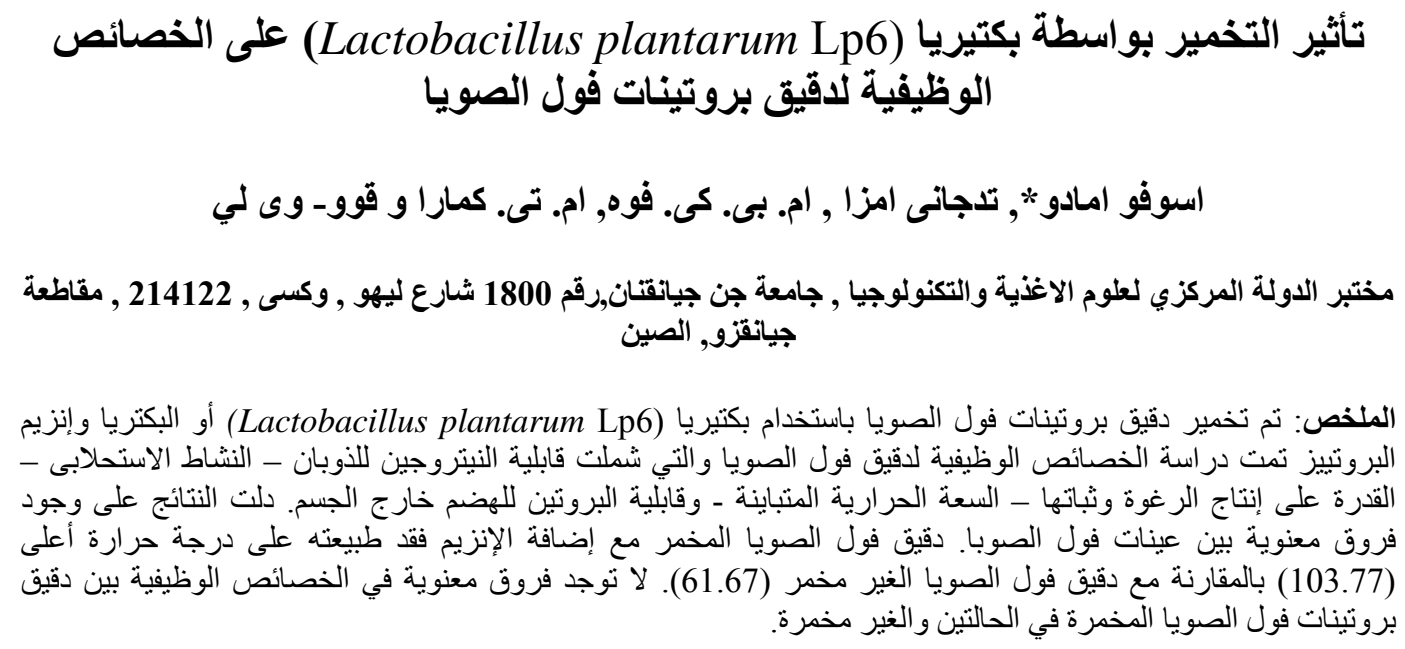

* Corresponding Author, Email: issoufsara@gmail.com 


\section{Introduction}

Soybeans are an abundant source of proteins that have been recognized for high nutritional value and excellent functional properties in food systems (Smith and Circle, 1976). Nowadays soybeans are grown primarily for the production of vegetable oil for human consumption but, as a by-product, soybean meal (SBM) is becoming increasingly important. On a global scale, soybean is dominating the market for protein meals due to its high protein content and good availability (USDA, 2003). Fermentation is known to be one of the oldest techniques in food manufacture and preservation that contributes directly into many advantageous properties of products by biochemical modification due to microorganisms' activities (Je et al., 2005; Hassaïne, et al., 2008).

Studies have confirmed that degradation of soybean allergens during fermentation by microbial proteolytic enzymes in soy sauce, miso, soybean ingredients, and feed-grade soybean meals (Hong et al., 2004; Kobayashi et al., 2005; Yamanihi et al., 1995). The nutritional and functional properties of legumes have been reported to improve generally by fermentation when compared to unfermented original products s (Granito et al., 2005). During fermentation and microbial growth, the functional properties of foods are formed as follows: protein is hydrolyzed to amino acids and peptides by proteolytic enzymes (Amadou et al., 2009; Sparringa and Owens, 1999; Kavitha and Predeepa, 2010), oligosaccharides are hydrolyzed to monosaccharides (Rehms and Barz, 1995), phytic acid degraded to inorganic phosphates (Sutardi and Buckle, 1988). Frias et al. (2008) showed that soybean flour fermented with Lactobacillus sp. ( $L$. plantarum) was able to further break down and use available proteins as nutrient sources. These properties are fundamental physicochemical characteristics, which affect the behaviour of proteins in food systems during processing, manufacturing, storage and preparation (Pablo et al., 2010; Kinsella, 1979). However, the effect of $L$. planturum Lp6 in combination with acid protease on their functional properties has not been investigated.
Therefore the objective of this study was to investigate the influence of L. planturum Lp6 fermentation on the functional properties of soybean protein meal.

\section{Materials and Methods Materials}

Commercial soybean protein meal and acid protease (Acid protease-537 from Asp.) were purchased from Sun-Green Biotech Co. Ltd (Nantong, China) and Sunson Industry Group Co. Ltd (Beijing, China) respectively. Trypsin, $\beta$-mercaptoethanol ( $\beta \mathrm{ME})$ and protein standard were obtained from Sigma-Aldrich, China Inc (Shanghai, China). The strain $L$. plantarum Lp6 was obtained from the culture collection of Jiangnan University (Wuxi, China). All other chemicals were of analytical grade.

\section{Fermentation and preparation of fermented soy protein meal}

The L. plantarum Lp6 stocks used was stored at $4{ }^{\circ} \mathrm{C}$ and cultured for $18 \mathrm{~h}$ at $37{ }^{\circ} \mathrm{C}$ in Man-Rogosa-Shape (MRS) broth from SunGreen Biotech Co. Ltd (Nantong, China) prior to use for fermentation. A $0.025 \mathrm{~mL}$ of $L$. plantarum Lp6 was prepared in sterilized distilled water and then mixed with $25 \mathrm{~g}$ of soybean protein meal $\left(10^{7} \mathrm{CFU} \mathrm{g}^{-1}\right)$ fortified with soluble starch $\left(0.4 \mathrm{~g} \mathrm{~g}^{-1}\right.$ of SPM $)$ and/or protease $\left(0.01 \mathrm{~g} \mathrm{~g}^{-1}\right.$ of SPM) in polyethylene bag $(140 \mathrm{~mm} \times 200 \mathrm{~mm})$ and vacuum sealed. Also $2 \mathrm{mg}$ of disodium phosphate $\left(\mathrm{Na}_{2} \mathrm{HPO}_{4} 12 \mathrm{H}_{2} \mathrm{O}\right)$ was added to improve the activity of $L$. plantarum Lp6, and then solidstate fermentation was performed for $72 \mathrm{~h}$ at $37^{\circ} \mathrm{C}$. The FSPM was dried overnight in a vacuum oven $\left(70^{\circ} \mathrm{C}\right)$ and stored in the desiccator until further use. Figure 1 represents the dried grinded SPM, FSPM and FSPMe as Figure $1 \mathrm{a}, 1 \mathrm{~b}$ and $1 \mathrm{c}$, respectively.

\section{Nitrogen solubility (NS)}

Nitrogen solubility was determined according to the procedure of Diniz and Martin (1997), with slight modification. Samples (SPM, FSPM and FSPMe) were dispersed in distilled water $\left(10 \mathrm{~g} \mathrm{~L}^{-1}\right)$ and $\mathrm{pH}$ of the mixture was adjusted to $2,3,4,5,6,7,8,9,10,11$ and 12 with either $0.5 \mathrm{~N} \mathrm{HCl}$ or $0.5 \mathrm{~N} \mathrm{NaOH}$ while 
continually shaking (Lab-Line Environ-Shaker; Lab-Line Instrument, Inc., Melrose Park, IL, USA) at room temperature for $35 \mathrm{~min}$ and 25 $\mathrm{mL}$ aliquot was centrifuged at $2800 \times \mathrm{g}$ for 35 min. A $15 \mathrm{~mL}$ aliquot of the supernatant was analyzed for nitrogen $(\mathrm{N})$ content by the
Kjeldahl method and the NS was calculated according to equation:

$$
\text { Nitrogen solubility }
$$

$\left(\frac{\text { supernatant nitrogen concentration }}{\text { sample nitrogen concentration }}\right) \times 100$

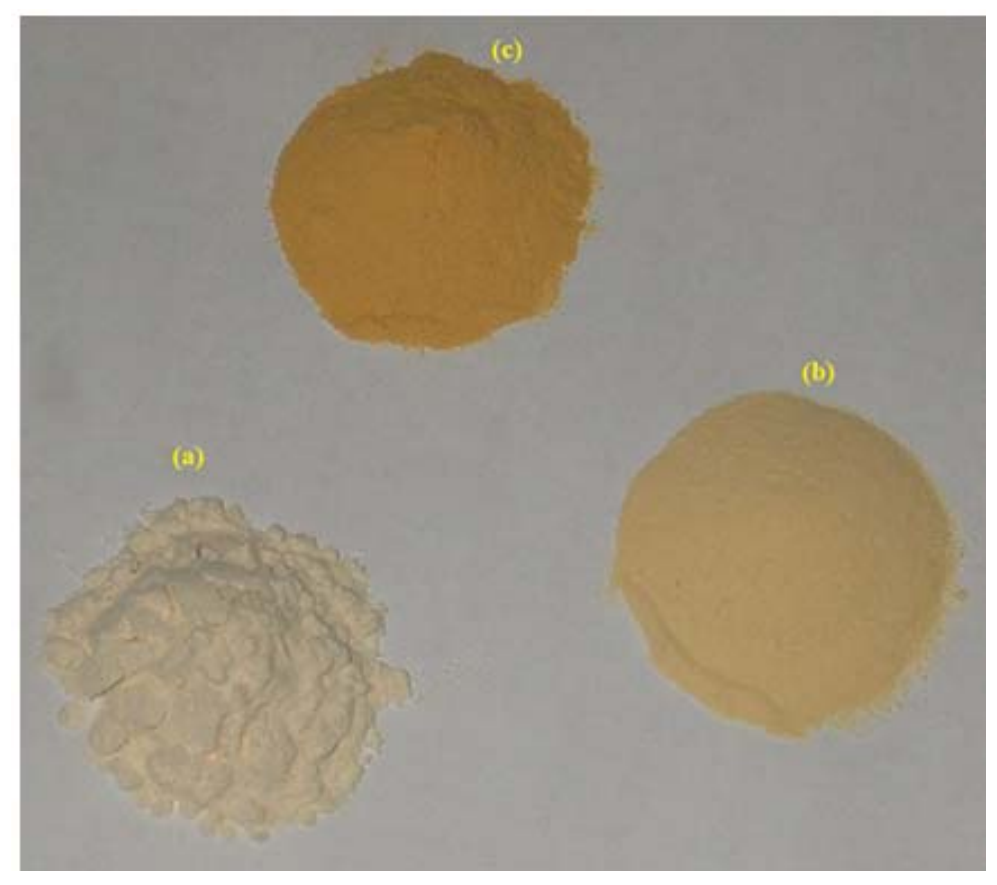

Figure 1. Soybean meals: (a) unfermented soybean protein meal "SPM", (b) fermented soybean protein meal "FSPM", and (c) fermented soybean protein meal with added protease "FSPMe".

\section{Water holding capacity (WHC)}

Water holding capacity (WHC) of soybean protein meal and fermented SPM was carried out according to the method of Diniz and Martin (1997), with slight modification. Triplicate samples $(0.5 \mathrm{~g})$ were dissolved with $10 \mathrm{~mL}$ of distilled water and vortexed for $30 \mathrm{~s}$. The dispersions were allowed to stand at room temperature for $30 \mathrm{~min}$ then centrifuged at $2800 \times \mathrm{g}$ for $25 \mathrm{~min}$. The supernatant was filtered with Whatman No.1 filter paper and the volume retrieved was accurately measured. The difference between initial volumes of distilled water added to the protein sample and the volume retrieved. The results were reported as $\mathrm{mL}$ of water absorbed per gram of protein sample.

\section{Oil holding capacity (OHC)}

Oil-holding capacity (OHC) of soybean protein meal and fermented SPM were determined as the volume of edible oil held by $0.5 \mathrm{~g}$ of material according to the method of Shahidi et al. (1995). A $0.5 \mathrm{~g}$ of each sample was added to $10 \mathrm{~mL}$ soybean oil (Gold Ingots Brand, QS310002012787, Suzhou, China) in a $50 \mathrm{~mL}$ centrifuge tube, and vortexed for $30 \mathrm{~s}$ in triplicate. The oil dispersion was centrifuged at $2800 \times \mathrm{g}$ for $25 \mathrm{~min}$. The free oil was decanted and the $\mathrm{OHC}$ was determined by weight difference.

\section{Foaming capacity (FC) and Foam stability (FS)}

Estimation of foaming capacity was done following the method of Bernardi Don et al. (1991), with minor modification. Thirty $\mathrm{mL}$ of $30 \mathrm{~g} \mathrm{~L}^{-1}$ aqueous dispersion was mixed 
thoroughly using an Ultra-turrax 25 homogenizer at $9500 \mathrm{rpm}$ for $3 \mathrm{~min}$ in a 250 $\mathrm{mL}$ graduated cylinder. The total volume of the protein dispersion was measured immediately after $30 \mathrm{~s}$. The difference in volume was expressed as the volume of the foam. Foam stability was determined by measuring the fall in volume of the foam after $60 \mathrm{~min}$.

\section{Emulsifying capacity (EC)}

Emulsifying capacity was measured using the procedure described by Yasumatsu et al. (1972), with modification. A $0.5 \mathrm{~g}$ of each freeze dried sample was transferred into a 250 $\mathrm{mL}$ beaker and dissolved in $50 \mathrm{~mL}$ of $0.5 \mathrm{~N}$ $\mathrm{NaCl}$, and then $50 \mathrm{~mL}$ of soybean oil (Gold Ingots Brand, QS310002012787, Suzhou, China) was added. The homogenizer equipped with a motorized stirrer driven by a rheostat Ultra-T18 homogenizer (Shanghai, China) was immersed in the mixture, and operated for 120 $\mathrm{s}$ at $10,000 \mathrm{rpm}$ to make an emulsion. The mixture was transferred to centrifuge tubes, maintained in water-bath at $90{ }^{\circ} \mathrm{C}$ for $10 \mathrm{~min}$ and then centrifuged at $2800 \times \mathrm{g}$ for $20 \mathrm{~min}$. Emulsifying capacity was calculated as in equation.

$$
E C=\frac{V_{A}-V_{R}}{W_{S}}
$$

Where $V_{A}$ is the volume of oil added to form an emulsion, $V_{R}$ is the volume of oil released after centrifugation, and $W_{S}$ is the weight of the sample.

\section{Bulk density (BD)}

Bulk density of soybean protein meal and fermented SPM was estimated with approximately $3 \mathrm{~g}$ of each sample in $25 \mathrm{~mL}$ graduated cylinders by gently tapping on the bench 10 times. The volume was recorded and bulk density was reported as $\mathrm{g} \mathrm{mL}^{-1}$ of the sample.

\section{In vitro protein digestibility}

In vitro protein digestibility (IVPD) was carried out according to the method described by Elkhalil et al. (2001), with slight modifications. Twenty $\mathrm{mg}$ of soybean protein meal and fermented SPM samples were digested in triplicate in $10 \mathrm{~mL}$ of trypsin $(0.2$ $\mathrm{mg} \mathrm{mL}^{-1}$ in $100 \mathrm{mM}$ Tris-HCl buffer, $\mathrm{pH}$ 7.6).
The suspension was incubated at $37{ }^{\circ} \mathrm{C}$ for 2 hours. Digestion was stopped by adding $5 \mathrm{~mL}$ $50 \%$ trichloroacetic acid (TCA). The mixture was allowed to stand for $30-35 \mathrm{~min}$ at $4{ }^{\circ} \mathrm{C}$ and was then centrifuged at $10,000 \times \mathrm{g}$ for $25 \mathrm{~min}$ using a D-3756 Osterode AM Harz Model 4515 Centrifuge (Sigma, Hamburg, Germany). The resultant precipitate was dissolved in $5 \mathrm{~mL}$ of $\mathrm{NaOH}$ and protein concentrate was measured using the Kjeldahl method. Digestibility was calculated as follows:

Protein digestibility $(\%)=\frac{(A-B)}{A} \times 100$

Where $A$ : total protein content $(\mathrm{mg})$ in the sample.

$B$ : total protein content $(\mathrm{mg})$ in TCA precipitate.

\section{Differential scanning calorimetry (DSC)}

Thermal denaturation of soybean protein meal and fermented SPM samples were examined with a Perkin-Elmer differential scanning calorimeter. Lyophilized samples (1 mg each) weighed in aluminum pans and 10 $\mu \mathrm{L}$ of distilled water added, using an empty pan as a reference. The scanning temperatures were from 30 to $120{ }^{\circ} \mathrm{C}$ at a heating rate of 10 ${ }^{\circ} \mathrm{C} \mathrm{min}^{-1}$. Indium standards were used for temperature and energy calibrations. Thermal denaturation temperature (Td) and denaturation enthalpy $(\Delta \mathrm{H})$ were calculated from thermograms.

\section{Statistical Analysis}

Data analysis was carried out with SPSS Inc. software (version 13.0). One-way analysis of variance (ANOVA) was used to determine significant differences between means, with the significance level taken at a $=0.05$. Tukey's HSD test was used to perform multiple comparisons between means.

\section{Results and Discussions}

\section{Nitrogen solubility}

Nitrogen solubility (NS) is used to measure protein solubility in water. This assay differs in the speed (and vigor), at which the water/soybean protein meal mixture is stirred. The NS assay has been extensively used to evaluate the meal quality. High solubility is very important to manufacturers of soybean 
meal and related product (Adler-Nissen, 1976). The effect of fermentation conditions on nitrogen solubility of SPM, FSPM and FSPMe are shown in Figure 2. More protein-protein interactions and fewer protein-water interactions occur around $\mathrm{pH} 4$ to 5 (Kinsella, 1979). FSPM and FSPMe have close solubility profiles (Figure 2); moreover, fermented samples exhibited the highest solubility values at alkaline $\mathrm{pH} \quad(99.15 \%$ and $97.14 \%$, respectively for FSPM and FSPMe), while under acidic condition, the unfermented sample SPM had higher solubility index (95.01\%).

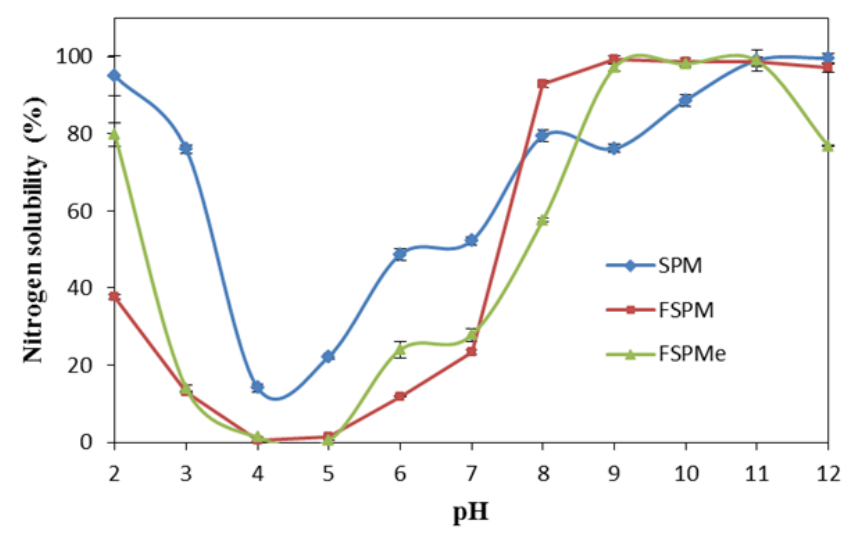

Figure 2. Effect of pH treatment on nitrogen solubility of fermented soybean protein meal samples. Values represent the means \pm standard deviation (SD) of triplicate
At $\mathrm{pH}$ 6.0, nitrogen solubility increased rapidly with an increase in $\mathrm{pH}$ up to 12.0 . This is in agreement with the findings of $\mathrm{Yu}$ et al. (2007) who also reported an increase in protein solubility of peanut protein concentrate following fermentation.

\section{In vitro trypsin digestibility}

The in vitro trypsin digestibility of SPM and fermented SPM samples were evaluated by the release of trichloroacetic acid TCA-soluble nitrogen, after incubation time of $120 \mathrm{~min}$ at $37^{\circ} \mathrm{C}$. Table 1 shows that the protein from both fermented and unfermented SPM exhibited significant trypsin digestibility. Fermented SPM with addition of protease affected more in vitro trypsin digestibility. However, fermentation of SPM exhibited significant increase of digestibility $(\mathrm{P}<0.05)$. Unfermented meal, FSPM and fermented meal with addition of protease (FSPMe) have digestibility values with trypsin of 83.48, 90.96 and $93.15 \%$, respectively. The increase in digestibility after fermentation may reflect that the positive influence on the protein digestibility was larger than the positive influence of protein degradation by the addition of protease. Our data corroborate with the investigations of Frias et al. (2008), who reported that, fermentation has the capacity to improve nutritional and functional properties compared to original product.

Table 1. Influence of fermentation on In vitro digestibility, water holding capacity, oil holding capacity, emulsifying capacity, bulk density and foam capacity of soybean protein meal (SPM), fermented soybean protein meal (FSPM) and FSPM with added protease (FSPMe) samples.

\begin{tabular}{|c|c|c|c|}
\hline & SPM & FSPM & FSPMe \\
\hline In vitro protein digestibility (\%) & $83.48 \pm 0.52 c$ & $90.96 \pm 1.09 \mathrm{~b}$ & $93.15 \pm 0.34 \mathrm{a}$ \\
\hline Water holding capacity $\left(\mathrm{mL} \mathrm{g}^{-1}\right)$ & $2.65 \pm 0.22 \mathrm{c}$ & $1.14 \pm 0.04 \mathrm{~b}$ & $0.79 \pm 0.03 \mathrm{a}$ \\
\hline Oil holding capacity $\left(\mathrm{mL} \mathrm{g}^{-1}\right)$ & $1.40 \pm 0.20 \mathrm{ab}$ & $1.57 \pm 0.06 \mathrm{~b}$ & $1.07 \pm 0.23 \mathrm{a}$ \\
\hline Emulsifying capacity $\left(\mathrm{mL} 0.5 \mathrm{~g}^{-1}\right)$ & $41.83 \pm 0.76 c$ & $28.01 \pm 0.99 a$ & $38.09 \pm 0.09 b$ \\
\hline Bulk density $\left(\mathrm{g} \mathrm{mL}^{-1}\right)$ & $0.63 \pm 0.02 \mathrm{a}$ & $0.72 \pm 0.02 \mathrm{c}$ & $0.68 \pm 0.01 b$ \\
\hline Foam capacity $\left(\mathrm{mL} \mathrm{mL}^{-1}\right)$ & $1.67 \pm 0.15 \mathrm{a}$ & $1.98 \pm 0.03 b$ & $2.06 \pm 0.05 b$ \\
\hline
\end{tabular}




\section{Water/oil holding capacity}

Interactions of water and oil with proteins are very important in food systems because of their effects on the flavor and texture of foods. On the other hand, functional properties of proteins in food system broadly depend on the water-protein interaction (Barbut, 1999).

However, food processing methods have important impacts on the protein conformation, surface polarity/hydrophobicity. The WHC values of SPM, FSPM and fermented SPM with added protease FSPMe samples were $2.65,1.14$ and $0.79 \mathrm{~mL} \mathrm{~g}^{-1}$, respectively.

Data obtained in this study show that fermentation reduced water holding capacity of soybean protein meal, whereas, little change was observed in oil holding capacity (Table 1). Hence fermentation significantly enhanced the water and oil retention of soybean protein meal $(\mathrm{P}<0.05)$. This is consistent with the results reported by (Ghavidel and Prakash, 2006; Hong et al., 2004).

\section{Emulsifying capacity}

The ability of proteins to form stable emulsions is important owing to the interactions between proteins and lipids in many food systems. Proteins are composed of charged amino acids, non-charged polar amino acids and nonpolar amino acids, which makes protein a possible emulsifier, the surfactant possessing both hydrophilic and hydrophobic properties and be able to interact with both water and oil in food system (Ghavidel and Prakash, 2006). As shown in Table 1 soybean protein have the highest emulsifying capacity $\left(41.83 \mathrm{~mL} 0.5 \mathrm{~g}^{-1}\right)$ followed by fermented SPM with added protease $\left(38.09 \mathrm{~mL} \quad 0.5 \mathrm{~g}^{-1}\right)$ and FSPM had the lowest value of $28.01 \mathrm{~mL} 0.5 \mathrm{~g}^{-1}$ probably this is due to proteolytic hydrolysis of protein by added protease during fermentation which increased the oligopeptides content and decreases the polypeptides. Fermentation significantly increased the emulsifying capacity of soybean protein meal $(\mathrm{P}<0.05)$. This study is in agreement with the results of Frias et al. (2008).

\section{Bulk density}

There were significant difference $(\mathrm{P}<0.05)$ among the various samples studied
(Table 1). SPM, FSPM and FSPMe showed closely values bulk density of $0.63,0.72$ and $0.68 \mathrm{~g} \mathrm{~mL}^{-1}$, respectively. However, SPM exhibited lower bulk density compared to fermented samples. Bulk density signifies the behavior of a product in dry mixes, and is an important parameter that can determine the packaging requirement of a product. Also it varies with the fineness of particles. The decreased bulk density would be an advantage in the preparation of weaning food formulations, where low bulk density is required Kamara et al. (2009).

\section{Foaming capacity and stability}

Proteins denature and aggregate during whipping to show a large increase in the surface area in the liquid/air interphase and rapid conformational change and rearrangement at the interface; the foam stability requires formation of a thick, cohesive, and viscoelastic film around each gas bubble (Petruccelli and Anon, 1994) hence foam ability is a function of the configuration of protein molecules. There is no major changes among the SPM and fermented samples in the foam stability (Figure 3), whereas, foam stability show a significant difference $(\mathrm{P}<0.05)$.

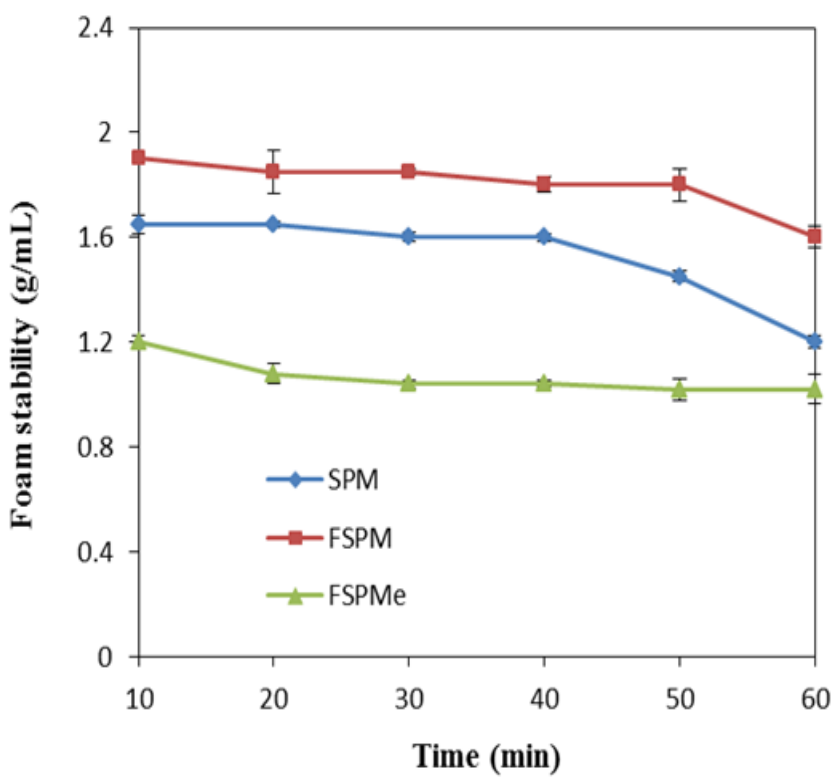

Figure 3. Foam stability of fermented soybean protein meal samples. Values represent the means \pm standard deviation (SD) of triplicate. 
Emir. J. Food Agric. 2010. 22 (6): 456-465

http://ffa.uaeu.ac.ae/ejfa.shtml
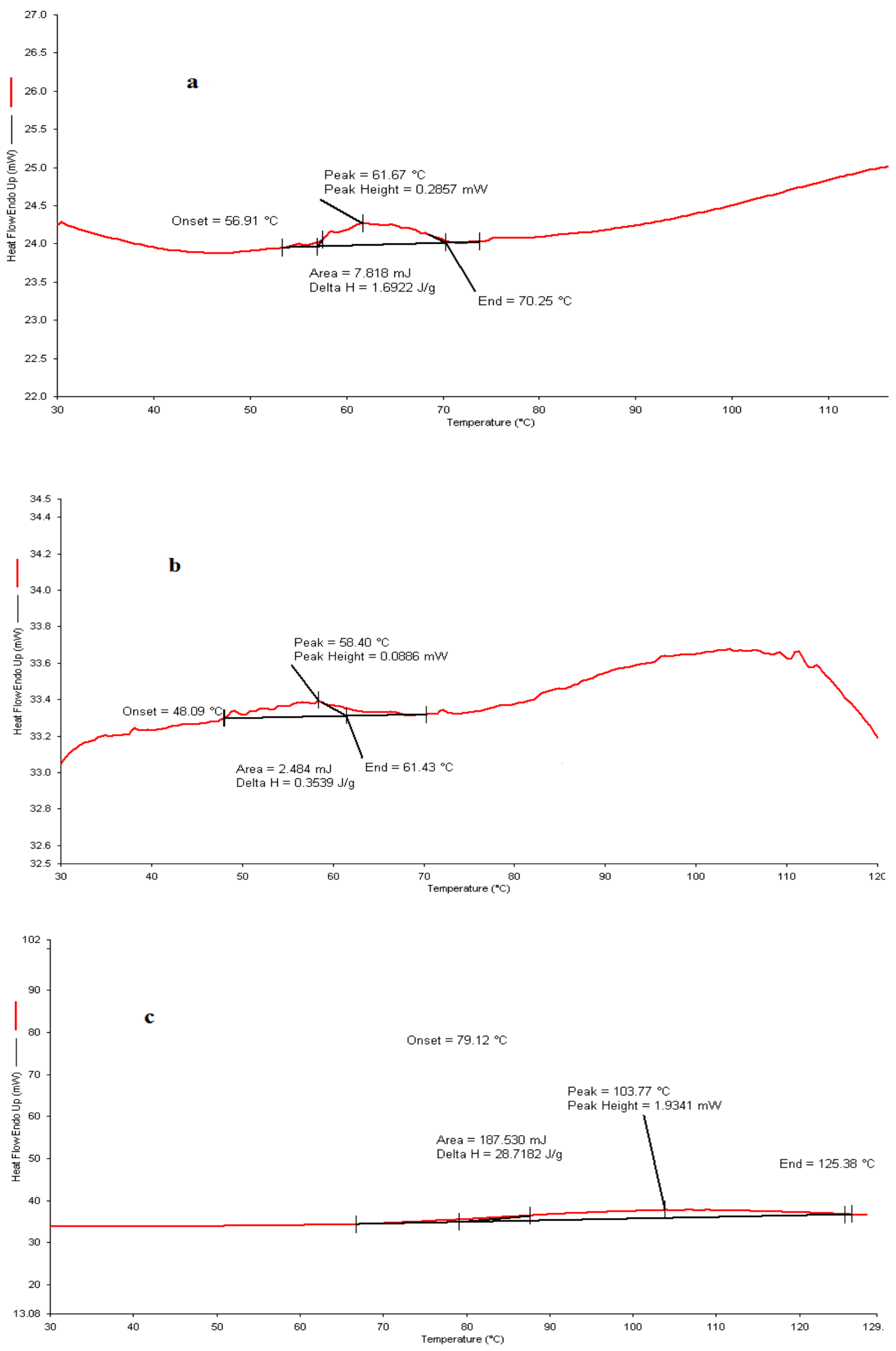

Figure 4. Thermal properties of: a) soybean protein meal "SPM", b) fermented soybean protein meal "FSPM", and c) fermented soybean protein meal with added protease "FSPMe". 
Samples of SPM, FSPM and FSPMe have a foam capacity of $1.67,1.98$ and $2.06 \mathrm{~mL} \mathrm{~mL}^{-1}$, respectively. The capacity of proteins to form stable foams with gas by forming impervious protein films is an important property and it was likely due to the increased net charges on the protein, which weakened the hydrophobic interactions but increased the flexibility of the protein. This allowed the protein to diffuse more rapidly to the air-water interface to encapsulate air particles and then enhance the foam formation (Wierenga and Gruppen, 2010). There is an increase in foam capacity and a decrease in foam stability when these soybean meal samples were fermented (Ghavidel and Prakash, 2006).

\section{Differential scanning calorimetry}

DSC is a valuable tool for assessing the potential of protein or related high protein content products as functional ingredients in different food systems. Because functional properties of protein meal products are greatly influenced by their conformation, therefore, DSC as a technique highly sensitive to conformational changes is often applied to protein hydrolysates and related products (Gorinstein et al., 1996). Data from DSC assessments for SPM, FSPM and FSPMe are given in Figure 4 (Figure $4 \mathrm{a}, 4 \mathrm{~b}$ and $4 \mathrm{c}$, respectively). Based on the results the samples have varied denaturation temperatures 61.67 ${ }^{\circ} \mathrm{C}, 58.40{ }^{\circ} \mathrm{C}$ and $103.77{ }^{\circ} \mathrm{C}$ respectively for SPM, FSPM and FSPMe. The enthalpy differs among unfermented and fermented meals. The enthalpies of the various samples as stated above were, 1.692, 0.353 and $28.718 \mathrm{~J} \mathrm{~g}^{-1}$, respectively. This data corroborate with the investigations of Hou and Chang, (2004) on soybean product stored under various conditions.

\section{Conclusion}

Although our previous investigations have demonstrated that fermentation with $L$. plantarum Lp6 improved the nutritional attributes of soybean protein meal. The functional properties of the fermented soybean protein meal showed a slight difference when compared to unfermented meal in most cases. These functional properties included the nitrogen solubility, emulsifying activity, foaming capacity, foaming stability, and in vitro protein digestibility. Therefore, fermentation with $L$. plantarum Lp6 in addition with protease shows a significant denaturation temperature which qualified the fermented meal to have huge potentials of value addition to the soy protein meal industry and provide food processors with nutritionally affordable source of plant protein. Fermentation with $L$. plantarum Lp6 offers a novel strategy to enhance the value of soybean protein meal and more studies are needed on its industrial application.

\section{Acknowledgement}

This research was supported by the National Natural Science Foundation of China (No.30671525), the National High Technology Research and Development Program ("863"Program) of China (NO. 2007AA10Z325), 111 project-B07029.

\section{References}

Adler-Nissen, J. 1976. Enzymatic hydrolysis of proteins for increased solubility. J. Agric. Food Chem. 24:1090-1093.

Amadou, I., J. Sun, M. T. Kamara, Y. H. Shi, O. S. Gbadamosi, and G. W. Le. 2009. Characterization, in vitro trypsin digestibility and antioxidant activity of fermented soybean protein meal with Lactobacillus plantarum Lp6. Am. J. Food Technol. 4(3):268-276.

Barbut, S. 1999. Determining water and fat holding. In G.M. Hall (Ed.), Methods of testing protein functionality (pp. 186225). New York: Blackie Academic and Professional.

Bernardi Don, L.S., A. M. R. Pilosof and G. B. Bartholomai. 1991. Enzymatic modification of soy protein concentrates by fungal and bacterial proteases. J. Am. Oil Chem. Soc. 68:102-105.

Diniz, F. M. and A. M. Martin. 1997. Effects of the extent of enzymatic hydrolysis on the functional properties of shark protein 
hydrolysate. LWT- Food Sci. Technol. 30:266-272.

Elkhalil, E. A. J., A. H. El Tinay, B. E. Mohamed and E. A. E. Elshseikh. 2001. Effect of malt pretreatment on phytic acid and in vitro protein digestibility of sorghum flour. Food Chem. 72(1):29-32.

Frias, J., Y. S. Song, M. V. Cristina, E. G. De Mejia and V. V. Conception. 2008. Immunoreactivity and amino acid content of fermented soybean products. J. Agric. Food Chem. 56(1):99-105.

Ghavidel, R. A. and J. Prakash. 2006. Effect of germination and dehulling on functional properties of legume flours. J. Sci. Food Agric. 86:1189-1195.

Gorinstein, S., M. Zemser and O. ParedesLopez. 1996. Structural stability of globulins. J. Agric. Food Chem. 44: 100 105.

Granito, M., A. Torres, J. Fias, M. Guerra and V. V. Conception. 2005. Influence of fermentation on the nutritional value of two varieties of Vigna sinensis. Eur. Food Res. Technol. 220:176-181.

Hassaïne, O., H. Zadi-Karam and N-E. Karam. 2008. Phenotypic identification and technological properties of lactic acid bacteria isolated from three breeds dromedary raw milks in south Algeria. Emir. J. Food Agric. 20(1):46-59.

Hong, K. J., Lee, C. H. and S. W. Kim. 2004. Aspergillus oryzae GB-107 Fermentation improves nutritional quality of food soybeans and feed soybean meals. J. Med. Food. 7(4):430-435.

Hou, H. J. and K. C. Chang. 2004. Structural characteristics of purified glycinin from soybeans stored under various conditions. J. Agric. Food Chem. 52(12):3792-3800.

Je, J. Y., Park, P. J., Jung, W. K. and S. K. Kim. 2005. Amino acid changes in fermented oyster Crassostrea gigas) sauce with different fermentation periods. Food Chem. 91(1):15-18.
Kamara, M. T., K. Zhu, I. Amadou, F. Tarawalie and H. Zhou. 2009. Functionality, in vitro digestibility and physicochemical properties of two varieties of defatted foxtail millet protein concentrates. Int. J. Mol. Sci. 10:52245238.

Kavitha, C., and R. J. Predeepa. 2010. Antibiosis of bacteriocins with domestic lactobacilli isolated from prepared curd. Emir. J. Food Agric. 22(5):398-405.

Kinsella, J. E. 1979. Functional properties of soy proteins. J. Am. Oil Chem. Soc. 56:242-249.

Kobayashi, M. 2005. Immunological functions of soy sauce: Hypoallergenicity and antiallergenic activity of soy sauce. J. Biosci. Bioeng. 100:144-151.

Pablo, D. R., T. P. Gabriela, C. A. María and E. L. Alberto. 2010. Optimization of additive combination for improved soywheat bread quality. Food Biopr. Technol. 3:395-405.

Petruccelli, S. and M. C. Anon. 1994. Soy protein isolates components and their interactions. J. Agric. Food Chem. 43:1762-1767.

Rehms, H. and W. Barz. 1995. Degradation of stachyose, raffinose, melibiose and sucrose by different tempe-producing Rhizopus fungi. Appl. Microbiol. Biotechnol. 44:47-52.

Shahidi, F., X. Q. Han and J. Synowiecki. 1995. Production and characteristics of protein hydrolysates from capelin (Mallotus villosus). Food Chem. 53:285293.

Smith, A. K. and S.J Circle. 1976. Processing soy flours, protein concentrates and protein isolates. In: K. Smith and J. Circle (Eds.) pp. 339-397. Soybeans: Chemistry and Technology, AVI publishing Co., Westport, CT.

Sparringa, R. A. and J. D. Owens, 1999. Protein Utilization during soybean 
tempeh fermentation. J. Agric. Food Chem. 47:4375-4378.

Sutardi, and K. A. Buckle. 1988. Characterization of extra- and intracellular phytases from Rhizopus oligosporus used in tempeh production. Int. J. Food Microbiol. 6:67-79.

USDA, ARS. 2003. National Genetic Resources Program. Phytochemical and ethnobotanical databases. [online Database]. National Germplast Resources Laboratory, Beltsville

Wierenga, P. A. and H. Gruppen. 2010. New views on foams from protein solutions. Curr. Opin. Colloid Inter. Sci. 15(5):365-373
Yamanihi, R., T. Huang, H. Tsuji, N. Bando and T. Ogawa. 1995. Reduction of the soybean allergenicity by the fermentation with Bacillus natto. Food Sci. Technol. Int. 1:14-17.

Yasumatsu, K., K. Sawada, S. Moritaka, M. Misaki, J., Toda, T. Wada and K. Ishi. 1972. Whipping and emulsifying properties of soy beans products. J. Agric. Boil. Chem. 36:719-727.

Yu, Y., M. Ahmedna and I. Goktepe. 2007. Peanut protein concentrate: Production and functional properties as affected by processing. Food Chem. 103:121-129. 